https://jurnal.ugm.ac.id/rubikon

\title{
COMMODIFICATION OF VALUES IN AMERICAN POPULAR FAMILY MOVIES IN 1990S
}

\author{
Siti Harsia \\ e-mail: sitiharsia@gmail.com
}

Ida Rochani Adi

Universitas Gadjah Mada

e-mail: idaadi@ugm.ac.id

\begin{abstract}
This thesis investigates the American popular family films from the 1950 s to the 2000s by using Interdisciplinary approach. This approach is intended to explore the object of research from the history, sociology, and cultural background. The theory of representation and commodification are used together to examine how the films represent American family life and how the film industry commercializes American family values. By focusing on family roles that include the division of roles between husband and wife, interactions between family members, and the values adopted by children as a result of parenting practice, it was found that the family concept shown in films from the 1950 s to the 2000s represented the reality of the dynamics of family life in every decade. Besides, in popular films of the 1990s, 'Hollywood Family Entertainment' commercialized the patriarchal issues contained in the 'traditional family' concept. There is an ideology of 'ideal woman' strictly as a housewife which was commodified through these films. Optimistic value in the family was also commodified through the child character consistently, shown by the emergence of child character who tends to be positive towards the future, focus on goals, strives for success and happiness and free in making choices.
\end{abstract}

Keywords: commodification; family film; ideal woman; optimistic; traditional-family

DOI $\quad$ : https://doi.org/10.22146/rubikon.v7i1.62507

Available at https://jurnal.ugm.ac.id/rubikon/article/view/62507

This work is licensed under a Creative Commons Attribution-ShareAlike 4.0 International License

\section{INTRODUCTION}

American film which is currently centered in Hollywood has become the most popular and Hollywood even said as the center of the
Article information

Received: 13 January, 2020

Revised: 27 January, 2020

Accepted: 10 February, 2020 entertainment industry throughout the world. It produced various genres of films that can be accepted by society at large. Thus, Hollywood films have a considerable influence in shaping the perspective of the people around the world 
in seeing a culture or a phenomenon. With these capabilities, Hollywood films can be used as a means for certain purposes through emotional playing techniques to direct the audience's perspective on a particular culture or interest.

During the era of baby boomers in the United States, families became a popular social topic, especially on television, as well as in film. As said by Levy (1990) that "the portrayal of the family in popular culture is an issue of great social and political significance because of the mass media's functions in the socialization for gender and family roles". So, the perspective of appropriate and inappropriate family roles showed not only by the family itself, but also by the mass media, including film. In case, in the 1980s American films showed the moral decline of family values. It can be seen by some films that portray the occurrence of family dysfunctional, such as the decreasing of mother's role, disharmony in brotherhood, and shifting father's role as non-patriarchal which is became the main reason for dysfunctionality or the decline of American family morals according to neoconservatives (Mayes, 2016).

Meanwhile, in 1990s, American film industry then produce some popular family movies, such as Home Alone (1990), Baby's Day Out (1993), Mrs. Doubtfire (1993) and Jingle All the Way (1996). These films became popular with achieving fantastic profits. Starting with Home Alone that first released in theaters on November 16, 1990 and became popular until today. In the first week of its screening, Home Alone occupied the top of the box office, generating \$17,081,997 in 1202 theaters. The film maintains number one position for 12 full weeks and stays in the top 10 until June of the following year. The film even managed to hold Guinnes' record in 1990 as the world's best-selling live-action comedy for 27 years. Then, Mrs. Doubtfire, which was released on November 24, 1993, Hollywood again achieved maximum profit and occupy second-highest-grossing film of 1993 worldwide with grossed $\$ 441.3$ million on a $\$ 25$ million budget. Besides, Baby's Day Out which was released on July 1, 1994 was played at the largest theatre in Calcutta for over a year and popular in several countries in Asia and India. The last, Jingle All the Way released on November 16, 1996 and "made \$ 129.8 million from a $\$ 75$ million budget" (Hewwit, 1996) in its screening throughout the domestic box office.

Finally, by using interdisciplinary approach, representation theory, popular culture theory, and commodification theory, this research investigated the depiction of American family life that shown in the films and how the film industry commodified the American values toward the films. This is also to answer whether the film industry consider the values and cultural elements in creating a work or focuses more on achieving maximum profits. The primary data in the research is all the content of Home Alone (1990), Mrs. Doubtfire (1993), Baby's Day Out (1994), and Jingle All the Way (1996). Some family films also choose as secondary data that help the writer to get more information as well as the deeper comprehension in making limitation whether the values in the films are the universal values or had commodified by the films production. Another data is collected through library and internet sources, such as books, journal, reports, articles, website, or online articles. 


\section{DISCUSSION}

\section{Family Life in American Popular Movies}

The emergence of family entertainment in Hollywood in 1930s was driven by the demands to produce works that are suitable for everyone and not adult- orientated movies only. It was a response to the many adultoriented films that hit the theme of 'sex films' which also became a children's show. This kind of viewing is certainly not suitable and can affect children's intellectual and emotional as well.

Since its inception in the 1930s, the Hollywood family films have continued to grow and become popular with fantastic profit gains for its productions and have won numerous awards in the world cinema. Noel Brown (2010) in his writing concluded that there are at least 2 reasons why Hollywood family films can be successful and accepted globally: first, Hollywood's international power facilitates the global proliferation of its product; second, Hollywood family films are designed to transcend normative barriers of age, gender, race, culture and even taste; they target the widest possible audiences to maximize commercial returns, trying to please as many people, and offend as few as possible.

However, the changes of values and family life in America also seems to be a concern of Hollywood entertainment or in other words the dynamics that occur in American family life are reflected through films that produced every decade, except the film in 1960an. Since 1930s until the mid of 1960s the American family film shows family harmony, both in extended families and nuclear families. In addition, the changes of family size are also a concern of Hollywood, for example, Cheaper by the Dozen (1950) which seems clarify the situation that "the 1950 decade was an era with high marriage and birth rates, low divorce, and stable family togetherness" (Hamer, 2017) and concur that "by midcentury a higher proportion of American children were growing up in stable, two-parent families than at any other time in American history" (Cherlin \& Fustenberg, 1988). The following snippets of text from the film Cheaper by the Dozen (1950, remake in 2003) show that family life in the decade had their strong function and social power as well. Besides, families as a cultural value also have a higher priority.

Tom Baker : :Well, I got a great team here, they such a support system in a home. Gonna back kids!" (pointing his family from the screen)

Sarah Baker : "Great. In Minland we were a family. Now were a support system?"

Lorraine Baker: "A family is a support system!"

As a system as mentioned above, the presence of Bakers' family member fulfills its function as a family institution where each family member must invest time, energy, love and care for the family.

Unfortunately, by the 1980s the narrative of family films in American cinema faced the significant changes. Family films are tinged with issues of disharmony in the family, divorce, violence, shifting the role of fathers and mothers, as well as other social instability issues. Films such as E.T: The Extra-terrestrial (1982) and Back to the Future (1985) confirm the issues and social dynamics that occurred at that time. The following scene in the film Back to the Future (1985) shown a picture of the decline in value and family life in America which is reflected through film: 

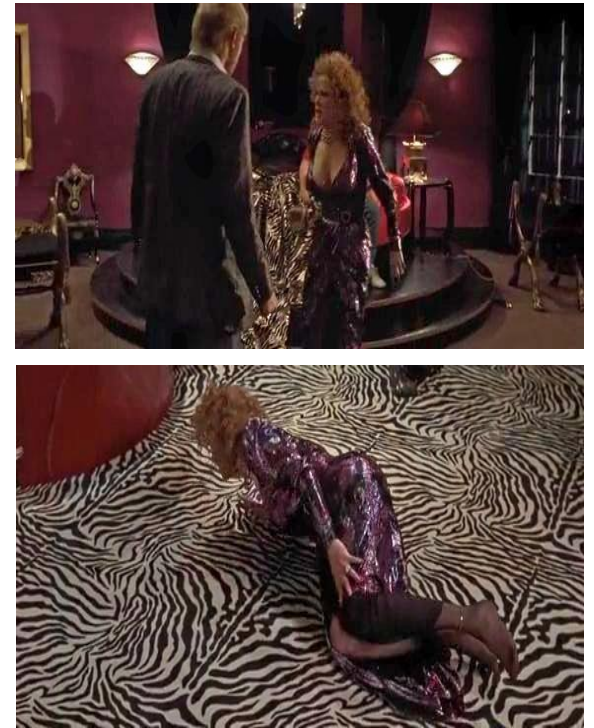

A squabbling with violence to the wife in Back to the future (1985)

Lorraine, who depended her life and her children on her second husband, Biff, chose to continue accepting all of Biff's decisions and still respect to Biff as a husband despite being treated violently from him. This phenomenon is explained by Cherlin (2014) as a form of familial changes and the collapse of traditional values. This change was influenced by various social dynamics throughout the 1970-1980s, such as culture wars that also caused the denigrating marriage, premarital sex and cohabitation. In addition, men generally consider themselves to be the main breadwinners and when they can earn more than their wives they tend to be rude to their wives.

\section{Commodifying Ideology of "Traditional Family" within American Modern Society}

By the 1980s the decline of family life in American cinema indicated by the domestic violence, loosening of relationships between children and parents, the behavior of husbands who have relationships with many other women, as well as wives' behavior that no longer reflects the characteristics of the "ideal woman" as trusted by American society as a good housewife who serve her husband and family. However, in the early 1990s, the emergence of Home Alone which shows again the role of the traditional family can be said become the turning point of the rising of family life in American family movies. In other words, Hollywood re-modifies the traditional family values and becomes the main concept of American family films. Traditional nuclear family, however, mentioned by Popenoe (2019) have the characteristics as follows: the family which consisting of a heterosexual, monogamous, life-long marriage in which there is a sharp division of labor, with the female as a full-time housewife and the male as primary provider and ultimate authority. This value is designated because since the 1950s, Hollywood showed consistency in representing family life in every decade by showing a picture of the rise and fall of traditional values in American families by following the social dynamics that occurred. The reappearance of traditional family values in the 1990s after having declined in the previous decade is an indication that the value is a selling point for Hollywood which also affects global audience acceptance.

Therefore, family films in the 1990s such as Home Alone, Mrs. Doubtfire, Baby's Day Out and Jingle All the Way all show significant differences from films in the 1980s, where the 1990s films had traditional family characteristics through harmonious family images and togetherness, except Mrs. Doubtfire (1993), and there is a clear division of task and role between husband and wife in the household. Firstly, Home Alone (1990) which was produced and released in 1990, received global attention and the Hollywood industry made huge profits and it even managed to hold Guinness record in 1990s as the 
world's best-selling live action comedy for 27 years. This success is certainly achieved not only because of the support of Hollywood marketing that is qualified, but also the fulfillment of the expectations of the audience toward the content of the film. In this case, the family context that is conveyed through the film can be a reflection of the family life aspired by many people, that traditional family role.

The characteristics of traditional family also appear in the film Baby's Day Out (1994) and Jingle All the Way (1996) where harmony and loyalty between husband and wife becomes the epicenter of the film's narrative. This shows that the values contained in the traditional family that also reflect the phenomenon of the decade gave a selling point and created an interest for the audience. The portrait of a happy married life, far from violence and quarreling, and focus on childcare, has turned into a commercial culture to reach a wide audience. Some scenes also show rejection to the issue of infidelity signifying the upholding of the principle of life- long marriage in 'traditional family'.

Beside those issues, the division of roles between husband and wife is one of the most popular in the 'traditional family' principle which states that the husband as head of the family have the ultimate authority, but is fully responsible for the family economy. On the other hand, the wife as the second position is fully responsible for household affairs, generally taking care of children, preparing all the needs of her husband and caring for the house.

Further, the dominance of the traditional family context has been demonstrated since the 1950s. Noted the film Father of the Bride (1950) and Cheaper by the Dozen (1950) promotes the concept of "ideal women", where the ideal woman is connoted as a good housewife, loyal to the family and fully devoted to her husband and children, where both in rich families and in the middle class family they do not work and only rely on the husband's income as a source of family economic support. Besides, in the 1950's the image of the "ideal" family was the successful husband, "when the children running in the garden or watching the brand-new television set and, above all, of the wife cooking in her highly-equipped kitchen, doing the laundry in the most modern washing machine and cleaning the house with her extremely powerful vacuum cleaner while wearing high heels and pearls and with an intact hairstyle" (Martin, 2011).

Hereafter, the film in 1965 's titled The Sound of Music still shows families with a large number of children and the mother's role as housekeeper while the father is fully career. The problems come when Mr. von Trapp's wife died and he was forced to take over his wife's duty to take care of the children. Father's parenting seems to be a serious problem because Mr. von Trapp did not have enough experience and time with his children. 

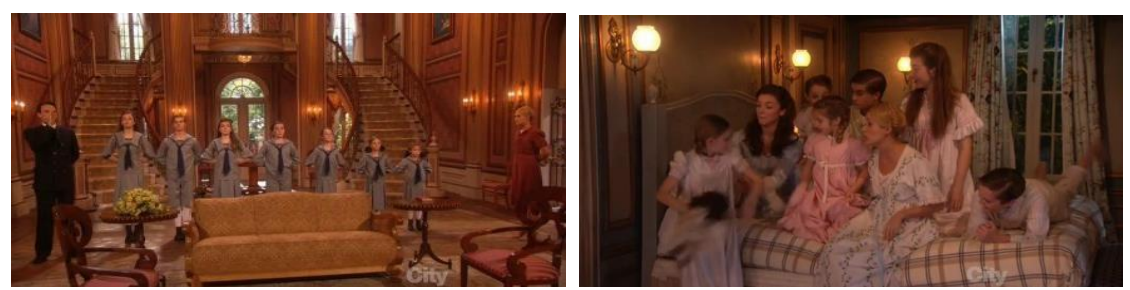

Mr. Von Trapp adopt a military way of caring for his child while Maria nurtures them with tenderness and affection in The Sound of Music (1965)

The different points of view about how to care for children as depicted above can be interpreted that a husband with all the achievements in his career is not enough to be a lesson in parenting. What is needed is an approach and togetherness with children to create a sense of sensitivity and understanding of what is needed by children. For this reason, women seem to be the right person to handle childcare issues and in the end the household is a place for women to have a career.

However, The Sound of Music (1965) portray the clear distinction between husband and wife' roles, although at first Maria Van Trapp as a stepmother had struggle with herself to choose whether continue her dream as a nun or marry and take care the children. This can be interpreted that women often have to give up their dreams in order to meet social and cultural demands in marriage where they have to dedicate their lives to take care for the family. Furthermore, women have been bound instinctively tend to be more touching in sharing love with others, especially to their children and husbands. Anyway, mothers in the family have their own place that cannot be replaced by anyone, intended a father. By all this way, it is quite clear to conclude that a woman's role as a housewife has been constructed by a culture based on the instinctive compassion that is in her and the structure of society that places women as the second position increasingly shaping their life that limited only on the 'family life'.

Hereafter, the rise of women's liberation movement and culture wars after the 1960s which gave women a great opportunity to enter the workforce eventually became the beginning of the change of family function. Women who are able to finance themselves no longer depend on their husbands so that their husbands lose their function as breadwinners. This leads to the increasing of divorce rates, the rise of premarital sex, and cohabitation. Brown marked "as the 1960s drew to a close, the traditional Hollywood family film had reached crisis point. The 1960s was a decade of renegotiation; it was a last hurrah for the traditionally-made family movie and by its close, U.S. popular culture was in the process of transitioning from an adult- to a youthorientation" (Brown, 2010).

Moreover, the 1970-1980s became decades of the rise of unwed motherhood because of "self-fulfillment" culture and the destigmatization of non-marital sex and child bearing. In other issue, the legacy of slavery caused the unstable sexual and familial lives of Black-American family. It created more single-mother families. The film E.T the Extra-terrestrial (1982) show us the role of women as a single motherhood and working. 


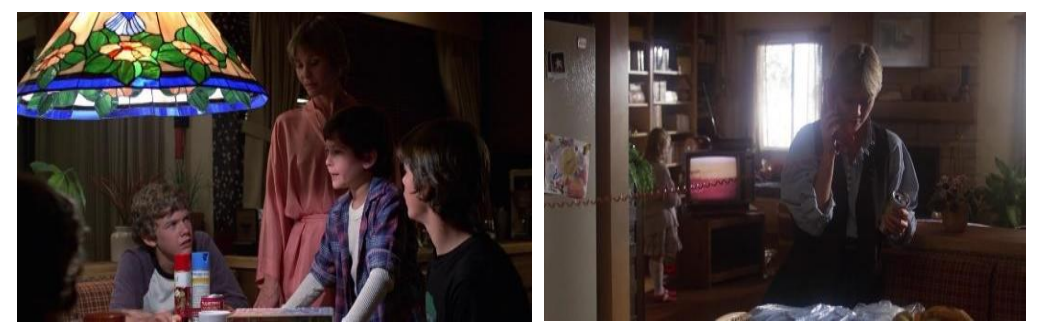

Mary fight as a single and working mother in E.T the Extra-terrestrial (1982)

The depicted family life above seems common in that era. After the crisis of the "ideal women" become the national issue and the need for the identity of women since the mid-1960s-1970s which lead to the feminist movement, many women have no doubts about separating from their husband because that movement gained the change of women's chance in workplace and confer women a stronger equality with men. With the power to provide for themselves, women are more prone to divorce their husbands and take the children with them. Fathers lose their position as the breadwinner and hereby a bit of their authority. However, by the 1990s through the film Home Alone, Baby's Day Out, Mrs. Doubtfire and Jingle All the Way, Hollywood revived traditional family values with a clear role limits between husband and wife and this seems have succeeded in making these films become popular. This success is certainly also supported by the appeal of the comedy genre that is displayed as well as a capable Hollywood promotion strategy as said by Kammen (1999) that cultural power depends on the production, promotion and dissemination of cultural artifacts. But somehow the emotional attachment of the audience to the content of the film that perpetuates the popularity of the film and make it remembered over the time. These four family films can answer the expectations of many people about how family life should be displayed. Starting from Home Alone (1990) featuring modern family life that is dominated by the emotional attachment of children and parents, especially mothers. Some scenes show that mother have more anxiety about the safety of children than other family members. The ideology of "ideal woman" in American is also raised in this film.

Similarly, the film Baby's Day Out (1994) also projects patriarchal family life where the husband has the authority in the family and be the center of breadwinner, while the wife being a housewife only. The presence of servants and baby sitter in the Cotwell family shows the life of the upper class family of American society, but after all Larraine Cotwell remains as the main housekeeper and does not take other work outside the home. However, the portrayal of a harmonious family in the 1990s films obscured the issue of patriarchy which was aggressively echoed by feminists in the previous decade. The film's narrative that places woman as a happy wife with an abundance of luxury and affection from her husband and her environment, makes it paradoxical but at the same time can meet the expectations of many people about how an 'ideal woman' should accept the consequences of her choice to be a housewife and let go of her career or all her achievements outside of married life. In other words, a happy family life with economic sufficiency is the goal of many people, especially a woman.

The same narrative is also built in the film Jingle All the Way (1996) which places women as housewives and husbands as breadwinners, 
even more extreme as a workaholic. However, at the end of the story family interests are above all, marked by the decision of Mr. Howard Langston for taking the role of real Turbo Man in the parade to give happiness to his son who really wants a turbo man doll as a gift on Christmas. Finally, the division of roles between husband and wife in the family requires a balance which increasingly complicated because the socio-cultural values in America are dynamic, diverse and followed by various conflicts of interest in the decade of 1960s-1990s.

Furthermore, by presenting the issue of divorce in the family, Hollywood is also successful with the film Mrs. Doubtfire in 1993. The film raised the value of equality for women in the family who choose to be a breadwinner and shifted the role of fathers who became more active and painstaking in caring for children. However, the income gap between husband and wife is one source of conflict within the household. This kind of thing confirms the situation of the wife in the previous decade, where the wife is more willing to take the decision to divorce from her husband when she feel financially secure. Even though the narration is a little different from the other 3 films, Mrs. Doubtfire (1993) on one hand is very thick with the promotion of the ideology of "ideal woman" as a housewife only. Any other busy life of a wife outside the home or when the wife enters the workforce and earns more income from her husband will open the opportunity for divorce in the family. At least that's what was described through this film. Hollywood's alignments on the issue of patriarchy are seen as a good thing for many people consciously or unconsciously, so that the cultural message carried can be accepted globally.

\section{Commodifying Child Optimism into Screen Adaptation}

In Hollywood, the effort to popularize the value of optimism in American society can be seen through some popular family films in the 2000s, such as Harry Potter (2003), The Chronicles of Narnias (2005), The Lovely Bones (2009), The Karate Kid (2010). Optimism values in various narratives are commodified through children's characters, such as Harry Potter who shows confidence that he can protect his school, Hogwarts and Gryffindor, in the series Harry Potter and the Chamber of Secret (2003) or the character Dre Parker in The Karate Kid (2010) who try to think positively and fight fear when others drops him. The optimistic value in this situation is related to the attitude of rejecting deviant behavior, violence, crime and other actions that result in loss and suffering. On the contrary, the emergence of positive energy encourages people to strive more for success and happiness in life, this is the end point of the optimistic value itself.

Regarding the family film in 1990s, Home Alone (1990) in some scenes showed the modification of the value of optimism in children who act as the main characters in the narrative. Kevin McCallister in the film shows the role of an intelligent, brave and optimistic child as an adult should be. However, the introduction of values is very dependent on the family environment. Kevin McCallister through the traditional family background as depicted in the film, certainly receives the impact of nurturing and the instilling of good values, such as optimistic values in problem solving. This optimistic value can also be seen in other scenes where Kevin is confident of being able to protect his house and his family property from thieves who come to his house. 
Moreover, another data also reveals that by merging adult characters into children's characters in the film can be accepted by more audiences. Through the film Baby's Day Out (1994), Hollywood again puts children as the central character. By combining fiction and reality narratives, the film succeeded in placing Baby Bink as the main character who carries the message and value for the audience. What is interesting to note is how the baby's imagination can grow beyond what is thought by adults. The character of infants in the film can be interpreted as human nature which, although irrational, but shows purity and positive feelings towards life. Baby Bink shows optimism and focus on what he wants to achieve with a happy feeling. This proves that children can be good media to convey moral messages in film. Thus, film can fulfill its function as a medium of learning for various audiences about life projections from diverse perspectives. Hollywood in this case also displays various values of life that more refer to the values of America itself.

\section{CONCLUSION}

Hollywood family film appeared as a response to the anxiety of some parties about the right film for children in the 1920s. This responded to the spread of adult films which hit with the 'sex theme' at that time which was also accessible to children and could affect children's intellectual and emotional as well. Then, Hollywood produces family films by following the genre trends. Hence, the family film genre in each decade can be identified, such as the popularity of the comedy- drama genre from the early 1940s to the end of the 1950 s, which became a trend in family film production in that decade. Also, the development of science and technology in the 1970 s to 1980 s which pushed the popularity of the science-fiction genre also became a trend for family films at that time. Followed by the action-comedy genre in the 1990s and the fantasy genre in the 2000s. This of course is part of the production strategy to meet market demand. Besides, Hollywood in producing family films also seems to pay attention to phenomena and dynamic social issues. From some popular movies chosen as subjects in this study show a lot of similarities in situations or in other words family films more represent family life in every decade.

Further, based on the analysis, it found that the concept of family shown in films from the 1950 s to the 2000s had the same reality in terms of the image displayed by each film. Film in the 1950s was dominated by the image as a happy family based on traditional family concepts. Traditional family, somehow, is characterized by a life-long marriage, harmony, there is a clear division of role between husband and wife, strong and financially solvent. The film Cheaper by the Dozen (1950) and Father of the Bride (1950) confirm the traditional or nuclear family model including two parents with dependent children in the home. Family looks harmonious with small or large numbers of children and the development of job opportunities and industry in urban areas. Subsequently, entering the 1960s, the film The Sound of Music (1965) was still consistent with the traditional nuclear family and image of patriarchal culture.

The social dynamics that began in the mid1960 s into the 1980s, such as the feminist movement in the mid-1960s and counter culture in the 1970s also influenced the lives of American families. In this case there was a crisis of family values in those years, such as culture wars which led to denigrating marriage, premarital sex and cohabitation. 
Responding to the family value crisis that occurred from the mid-1960s to the 1980s, the data analyzed showed that family films also projected a decline in value in the 1980s, such as E.T The Extra-terrestrial (1982) which showed the changing of family life marked by the crisis of the "ideal woman" that leads to the shifting of mother's role and the emergence of single-parent family. In the 1990s, Hollywood commodified American values into its films by reviving the traditional family ideology marked by the reappearance of patriarchal issues with a clear division of roles between husband and wife, and stable family togetherness. The emergence of such films meet the expectations of the audience and Hollywood successfully reflects these expectations through the traditional family role, means that the values in the traditional family have a sale value and become an interesting thing for the audience. The portrait of a happy married life, far from violence and quarreling, life-long marriage and focus on childcare, has turned into a commercial culture to reach wider audiences.

Through data analysis, it found that an important issue in the traditional family is the mother's role in a married life. Traditional families that closed related to the patriarchal system put women in the second position as housewives. This role is promoted through the concept of "ideal women" which is connoted as a good housewife, loyal to the family and fully devoted to her husband and children, and makes the husband as the main source of family's finances and economic support.

Further, data shows that popular films in the 1990s promoted the concept of "ideal women" as a housewife only. The film Home Alone (1990) shows that in modern American family life, women remain as a primary caregiver for children. The luxury of a wife's life is not a reason for her to ignored her role as a child care and also take care for husband and home. The film Baby's Day Out (1993) also confirms the same thing. Through a portrait of the happy life of the upper class American family, the film's narrative places the wife as housewife only and the husband has the authority in the family and becomes the center of breadwinner. Furthermore, Jingle All the Way (1996) by touching the issue of workaholic husband further clarifies the position of Hollywood that seeks to popularize the concept of patriarchy within the American family. Moreover, other data show that when a wife enters the workforce and earns a greater income from her husband, it will open the chance for divorce. Through the film Mrs. Doubtfire (1993) it can be seen that women who choose to become breadwinners in the family trigger conflicts over the division of roles in childcare. This film, however, is a form of support for the ideology of "ideal women" as a housewife only who criticizes the lives of career women who hand over childcare to others.

Besides, popular films in the 1990s also popularized the value of optimism through children's character. This makes family film become a media representation for younger audiences about interactions within the family and the community and about life projections through diverse perspectives. From the data obtained that the delivery of optimism value through children is conveyed by merging adult characters into children character who tend to be positive toward life, dare in making decisions, focus on goals and have a sense of protection. The optimistic value in the film is also related to a positive attitude towards the future, an attitude of rejecting suffering and seeking happiness and freedom in choosing 
the future. Optimistic values are displayed through various narratives, but with the same goal. Hollywood nevertheless continues to popularize these values in its work and of course by expecting maximum profit in return. The commodification of optimistic values in children eventually continued and became an important point in family films throughout the 2000s.

\section{REFERENCES}

Brown, Noel. (2010). Hollywood, the Family Audience and the Family Film, 19302010. England: Newcastle University

Cherlin, A \& Furstenberg, F.F, Jr. (1988). The Changing European Family: Lesson for the American Reader. Journal of Family Issues, 9, 291-297

Hammer, Ashley. (2017). Traditional Family Values Were Invented in the 1950s. Retrieved from http://curiosity.com/topics/traditionalfamily-values-were- invented-in-the1950s-curiosity/

Hewwit, Chris. (1996). Arnold Plans Visit with Jingle on November, 16. Minnesota: St. Paul Pioneer Press

Kammen, Michael. (1999). American Culture, American Tastes: Social Change and the Twentieth Century. New York, NY: Knopf

Levy, Emanuel. (1990). The American Dream of Family: Ideals and Changing Realities. New York: Continuum

Levy, Emanuel. (1991). The American dream of family in film: From decline to comeback. Journal of Comparative Family Studies, 22(2), 187-204

Mayes, Jeremi. (2016). Back to the Future: In 1980s American Family Values were Perceived to be in Moral Decline. How was this Decline Represented in American Popular Culture and What was the Suggested Remedy? History Initiates, 4,
$37-45$.

Popenoe, D. (1993). American Family Decline: A Review and Appraisal. New York: National Council on Family Relations

Vanessa, Martins Lamb. (2011). The 1950's and the 1960's and the American Woman: the transition from the "housewife" to the feminist. Universite du Sud Toulon-VaR 